\title{
From Southern Deserts to Northern Sand Dunes
}

\author{
by George F. Ledingham, Regina*
}

In the June issue of the Blue Jay the associate editors mentioned the absence of the editor and expressed the hope that an explanation of his absence might be given in the September issue. The following is an attempt to describe some of my experiences on trips which took me ten thousand miles and which extended from the deserts of the southwestern states and northern Mexico to the sand dunes on the southern shore of Lake Athabasca.

From April 22 to May 9 I had the exceptional good fortune to be able to join three professional birders on their trip through New Mexico, Arizona and California. They were looking for birds which they had not seen in their native Toronto or in

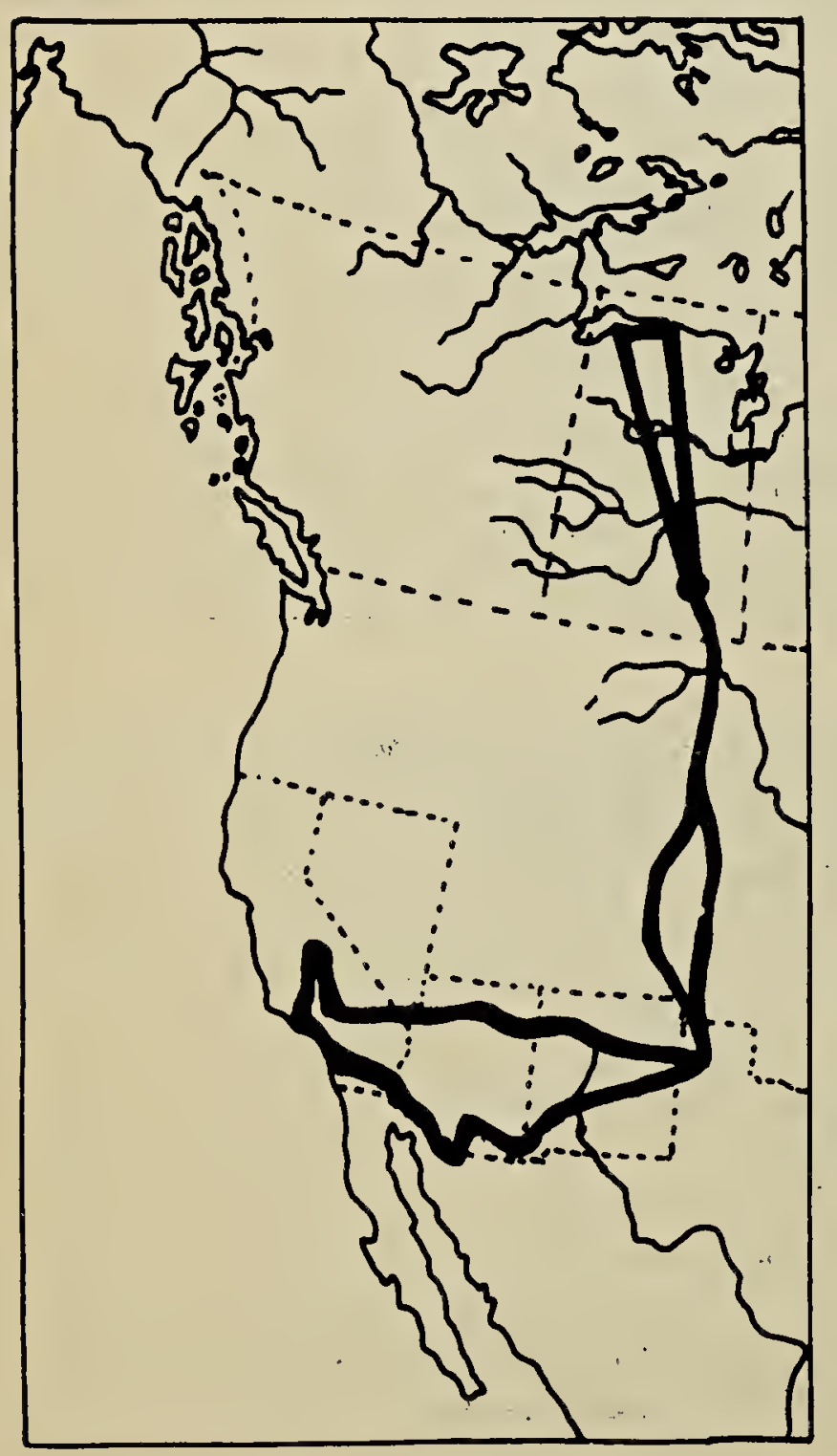

their travels in eastern North America. They knew where and how to look, and they were each successful in seeing about fifty 'lifers' (birds which they had not seen alive before). Naturally your editor, with his more limited previous experience with birds, saw more 'lifers' and he was able to add 100 birds to his life list. It was a wonderful experience.

In late June a second opportunity presented itself, and from June 26 to July 4, I was able to join an ornithologist and a botanist on their expedition into the unexplored regions on the south shore of Lake Athabasca. Although the purposes of the two trips were different they may perhaps be commented on briefly together, for they did both go into wilderness areas almost completely uninhabited by man. The trip to the south, which covered 8,000 miles, was made by car and so we used roads and motels and saw people every day, but the roads led to isolated spots where no one else would be seen for hours at a time. The trip to the north was made by plane into a spot where there was no evidence that man, of any race, had ever been before. We were to see no one for a full week, but rains and winds began about that time so we had a couple of extra days before a plane came in to see how we were faring in our tent and in our travels on foot and by light metal canoe.

My companions on the first trip were all expert birders. Jack Livingston, until recently managing director of the Canadian Audubon Society, provided the car for the trip, a big station wagon which was easily able to contain the four of us, our cameras and telescopes, a cooler and my bulky plant presses. Bill Smith, a veteran Toronto naturalist, had done the book and map work to schedule the tour

\footnotetext{
*The author is grateful to the Institute of Northern Studies: University of Saskatchewan, Saskatoon, for" financial assistance for the northern part of this trip.
} 
which successfully put us in the right spot in three States so that we could see a maximum number of new birds. Jim Baillie, ornithologist at the Royal Ontario Museum, University of Toronto, continued his weekly wildlife column in The Telegram so news of our trip appeared in the Toronto paper in four Saturday editions from April 28 to May 19.

My companions on the second trip were Dr. R. W. Nero and Dr. George Argus. Bob Nero is already well known to readers of the Blue Jay, for he is associate editor and a past president of our Saskatchewan Natural History Society. Bob was Assistant Director of the Saskatchewan Museum of Natural History for six years and it was while he was in this position that he began a study of the Birds of Lake Athabasca. This year, his work is being supported by the Institute for Northern Studies and by the Regina Natural History Society. Bob is now Professor of Biology, University of Saskatchewan, Regina Campus. Bird records of our trip, and there were some significant new records while I was with the party, will be published later this year in an important special publication of the S.N.H.S. George Argus is a botanist, but like Bob Nero he has wide interests and considerable experience in field work. He has a post-doctcrate fellowship from the National Research Council and is working on the native plants of Saskatchewan. George is especially interested in the willows; we hope that he will publish scme of his research papers in the Blue Jay.

Since the first trip took me farther from my native southern Saskatchewan home it brought me more surprises and thrills. I will not bore you with the list of new birds seen, nor will I try to mention the many hundreds of plants which were new to me. I did make over 100 collections of plants, most of which I have not yet had time to identify completely, and some of these were species of Astragalus and Oxytropis which I had been especially anxious to find for my research. Every day brought new sights, but I felt all the time that I would have to stay much longer to gain a real appreciation of the many different plant communities.

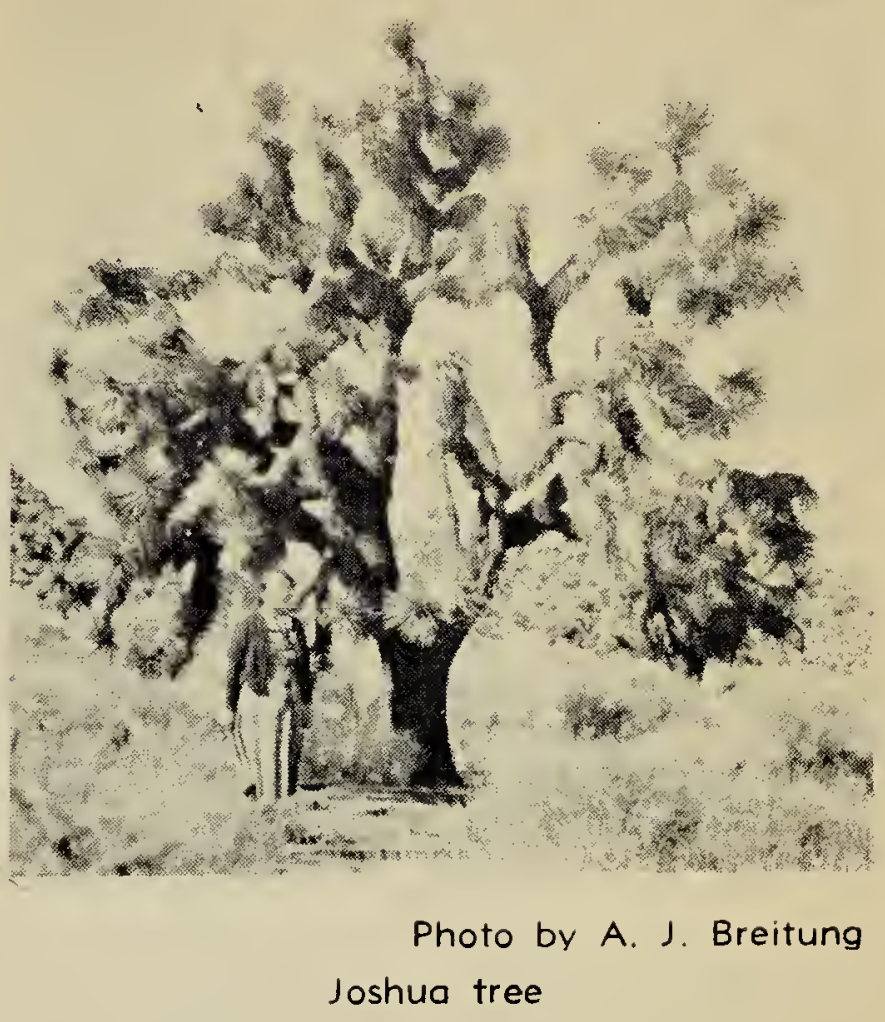

The most startling region to me was the desert. We passed through many different kinds of desert: one day it would be a yucca desert, the next might be a creosote desert, or a mesquite desert or a cactus desert. There were many kinds of cactus deserts; at different times the dominant cactus would be saguara, or cholla, or crganpipe or prickly pear. The yucca deserts were of different kinds and the most startling contained the Joshua tree.

The desert of the Great White Sands National Monument seemed bare and empty. When we walked in the area, however, we found many tracks of birds and other animals, and where there were a few plants these were species especially adapted to their environment. As in other regions, one had the great desire to stay longer to learn how all of the living things of the area survive.

All of the deserts were rather forbidding, for many of the plants in them were prickly with thorns. Many of the plants had no leaves; for example, the many kinds of cacti. I was interested to find other plants with poorly developed leaves, e.g., the beautiful paloverde (Spanish for "green trunk"). It was in flower during the time of our trip but usually there were no leaves on the plant. I 


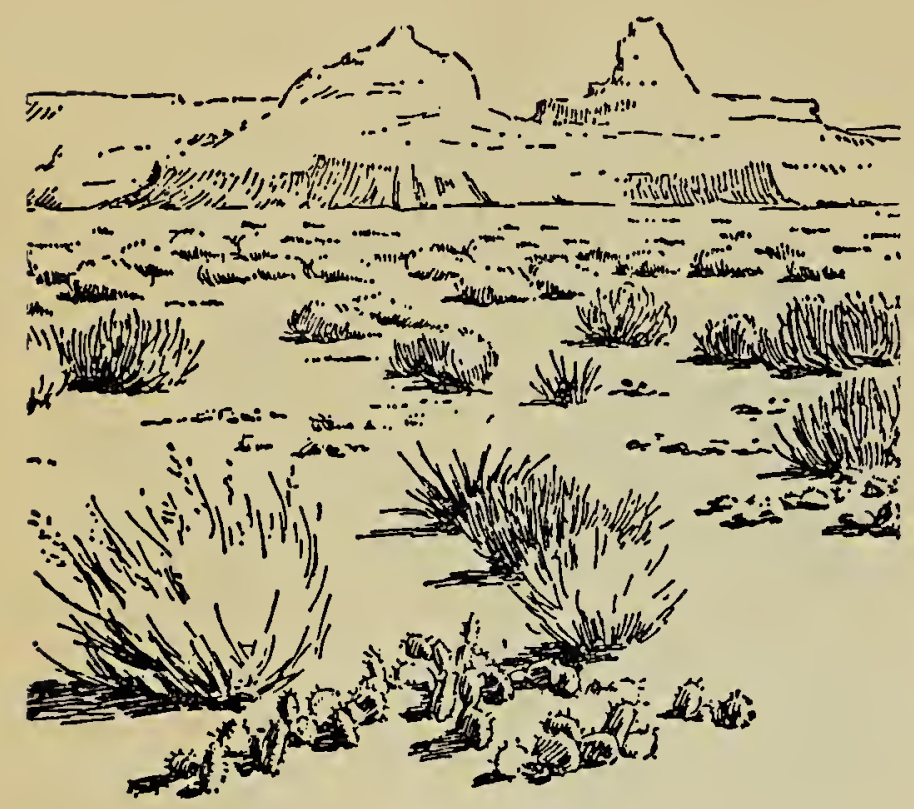

learned that the paloverde does form leaves under favorable conditions. These are compound leaves, as in other legumes, but each leaflet is very small. The leaves soon drop, and then through most of the year the green trunk and branches of the plant manufacture the food needed by the plant.

Some of the deserts were very beautiful. In one place near Deming, New Mexico, it was Escholtzia, the Californian poppy, which gave almost continuous colour to the landscape. In some places a great show of colour was provided by the sand verbenas. Sometimes the tough, old, usually prickly perennials - including the cacti-were in bloom; and sometimes most of the bloom was provided by hundred of quick-growing and dainty annuals.

It was hard for a stranger coming suddenly from winter in Saskatchewan to understand what was going on in these southern deserts. It would seem that rains are scarce in these regions, but sometimes there is sufficient rain to produce a riot of colour. Other regions, not so fortunate, would wait and maybe get enough rain next year. We did not spend all of our time in the deserts. They were usually simply regions that must be traversed in going from one good birding place to another. There were, however, some birds found only in the deserts; for example, the road runner, Bendire's and curve-billed thrashers, the whitenecked raven which replaces! the crow, scaled quail and the beautiful black-chinned sparrow.

From the deserts we passed at intervals into hills or mountains. Some of these were dry and we saw trees losing their leaves in preparation for the dry summer. In the canyons and covering many hills and mountain slopes, there were many kinds of fertile forests; one of these in the Sierra Nevada IMountains contained the giant Sequoia.

In the dry San Luis Mountains, west of desolate Antelope Wells, I saw my first vermillion flycatcher. In the famous Chiracahua Mountains of the land of Cochise I saw my first black-throated gray warbler, bridled titmouse and acorn woodpecker. In the Santa Rita Mountains I saw my first hepatic tanager and brown towhee. Each day brought new birds' to the list. In the Tucker Bird Sanctuary I not only saw my first Anna's and black-chinned hummingbirds, but we were able to sit comfortably and see them feeding just a few feet away.

We did take time for some things besides birds and plants. We watched the little horned lizards, a clumsy-

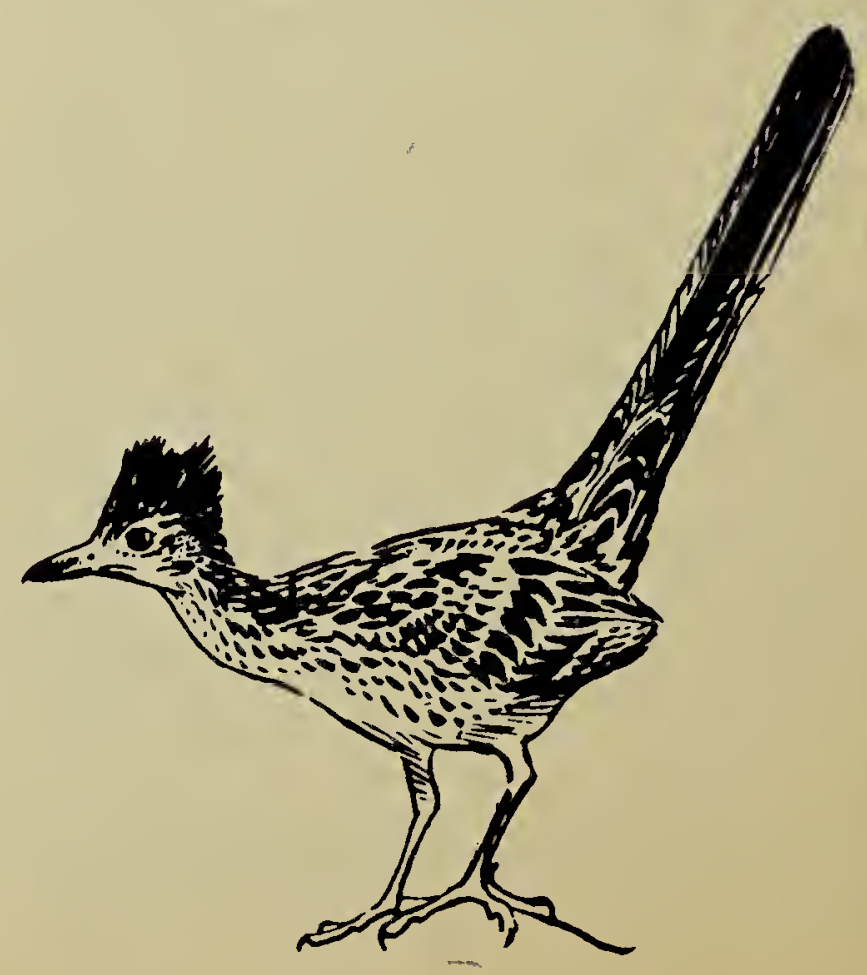


looking chuckwalla and other small lizards but we did not see a single rattler. Twice we were fortunate enough to see the famous, and now very rare, antelope jackrabbit. One of the biggest thrills of the trip for me was the once-familiar evening serenade of the coyote. The sound was a thrill partly because it was so unexpected. We had gone out in the dark in the Kaibab National Forest to listen for owls. We heard no owls but were rewarded by the coyotes. It was on the Kaibab Plateau that a programme to eliminate the predators (puma, wolf and coyote) was begun in 1907 with the mistaken idea that this would help the deer. The population of the deer increased so greatly that for years (1924-1936) the deer starved. Signs of overgrazing are now gone from the area, and predators will not be eliminated again.

Space and time do not allow me to mention even all the highlights of such a memorable trip. That there were more you will understand when I point out that I have not mentioned the Grand Canyon nor the Pacific Ocean. Actually, these are not much more startling nor beautiful than the sand dunes and bogs which we visited in northern Saskatchewan.

Here, on the south shore of Lake Athabasca, we saw more than one hundred square miles of drifting sand dunes. The sand is always moving when it is windy-and it is usually windy. Apparently the sand drifts in winter as well as in summer. We found that the sand may even move immediately after a good three-day rain. The sand as it moves forms banks twenty, thirty even forty feet high. These, as they advance over the country, completely cover the black spruce and jack pine forests. At the same time as forests are being buried with sand, other forests are being uncovered so that there are regions of dead sand-worn trees and stumps standing out on the naked sand plains. Depressions in the sand collect water and plants soon start to grow, but these may soon be buried with sand again. The complex succession of plants and animals in this region would make a most interesting study.

We spent much time on the sand dunes, and when we were not looking at living plants or animals we were

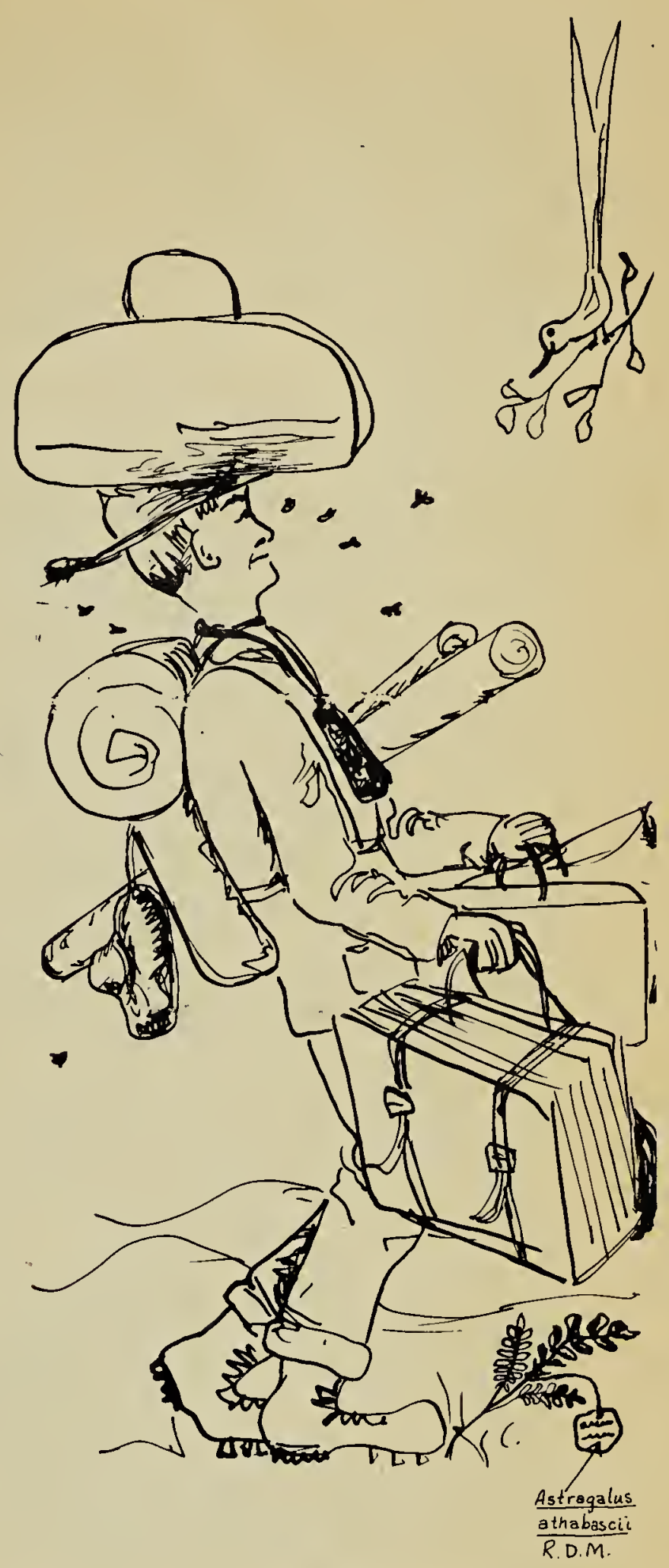

Sketch by Ruth Bennett

The Editor in the north

usually following tracks. In this way we learned much about the activities of moose and wolf and about smaller mammals and birds. The reason for the common name of the sandhill crane was forcefully brought home to us, for we often saw their tracks apparently going for miles over the sand dunes; twice we surprised them in the dunes. A pair of cranes were naising their young in a marsh not far from our camp so we frequently heard and saw them. It was indeed a thrill to see these fine birds, previ- 
ously known to us only in migration, in the bogs and marshes and sand dunes of northern Saskatchewan.

I saw sixty-six species of birds during my short stay in the north, but I need say no more about them for you will soon be reading all about them in Dr. Nero's Birds of the Lake Athabasca Region.

I hated to leave this camp on a little lake some eight miles south of Lake Athabasca. Our blue lake was dotted with lovely islands. When the wind blew one could still explore the many sheltered bays and quiet little ponds. The shores were all lush with orchids, pitcher plants, sundews and many species of moss, willow and sedge. The low, wet areas contained black spruce; the sand ridges were rather sparsely covered with reindeer lichen and jack pine. There was considerable evidence of caribou and ptarmigan having visited the area in winter.

The longer we stayed, the more there was to see. Part of this may have been due to the animals who seemed to get accustomed to us. When our tent had been up for several days, loons and beaver came close in shore as if to inspect us. One night two moose came to within a few feet of our tent, and we saw moose feeding several times in marshy areas nearby. The night before I was to leave the camp, we heard a wolf and I felt that the trip was successful-that I had really been in the northern wilderness far from civilization! The next day to make doubly sure I was satisfied and would return to visit the north again, one large whitish wolf appeared on a sandy ridge less than 200 yards from our camp. He looked us over and disappeared, but he had left us some nice 4 " $\times$ 5" footprints.

My travels are over for this year. They leave me more convinced than ever that there is still wilderness, both in the United States and in Canada, These wilderness areas are worth conserving but here in Canada we have not yet done much to set aside or protect them.

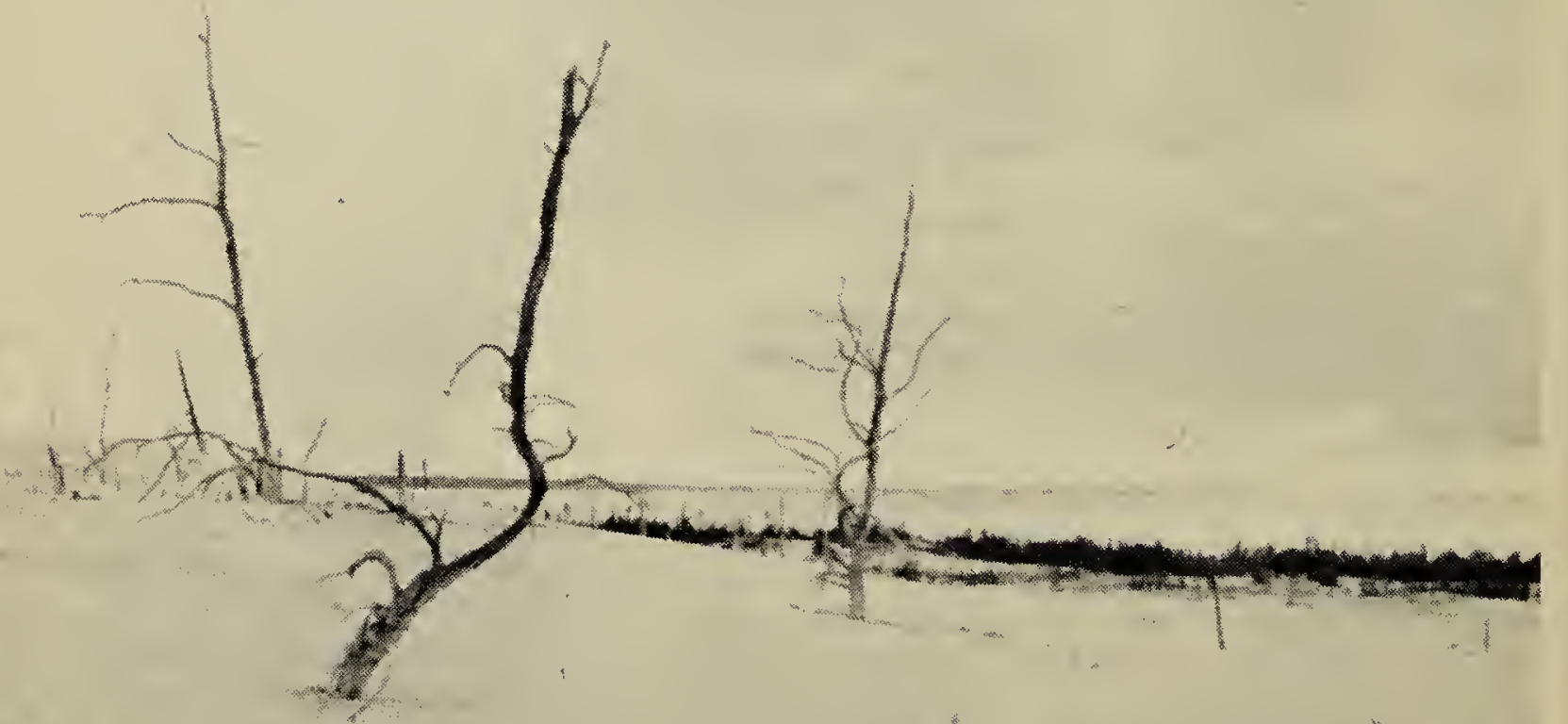

